\section{BJOS

Volume 17

2018

e18887

\title{
The importance of student monitoring in academic learning: a two-year follow-up
}

Gabriel Pereira Nunes' ${ }^{1}$ Beatriz Ommati Pirovani', Hiago Guimarães Silva ${ }^{2}$, Ana Victória Butarelo', Juliana da Silva Rossini', Jefferson Martins Costa ${ }^{3}$, Larissa Pereira Nunes ${ }^{4}$, Karina Vieira Martins ${ }^{3}$

\section{'School of Dentistry, São Paulo State University "Júlio de Mesquita Filho"/Brazil \\ 2School of Engineering, Federal Technological University of Paraná/ Brazil \\ ${ }^{3}$ Faculty of Science and Technology, São Paulo State University "Júlio de Mesquita Filho"/Brazi \\ ${ }^{4}$ School of Dentistry, Guarulhos University/Brazil}

\author{
Correpondence to: \\ Gabriel Pereira Nunes \\ School of Dentistry, São Paulo State \\ University "Júlio de Mesquita Filho"/ \\ Brazil. \\ gabriel.pereira.nunes@hotmail.com \\ Received: April 11, 2018 \\ Accepted: May 30, 2018
}

Abstract: Monitory exercises must provide conditions that support academic and personal development for students during graduation, once it allows a leveling possibility whereas the monitor meets the demands from the students in earlier years. Aim: This study has as objective to analyze the importance of monitory in advantage of the best academic achievement in students. Methods: In the years of 2015 and 2016, sophomore odontology students were monitored on pharmacology, originated from the need of remedial studies due to its high incidence of failure. For such, weekly monitoring on theoretical classes, study groups and content reviews were done. After two years of monitoring the number of failures and respective percentages were determined. The data was submitted to variance analysis and Student-Newman-Keuls test $(p<0,001)$. Results: The monitory had expressive results, since it reduced significantly failure numbers, statistically much inferior than previous years. Conclusion: Hence, it was possible to verify that monitory had positive effects on students learning, allowing access to knowledge and being imperative to the covered content systematization on the subject, since advising and monitoring students made their learning more natural. Keywords: Student monitoring. Learning. Pharmacology. 


\section{Introduction}

Academic monitoring is characterized as a program to foster education, arising from the need and importance of contributing to the advance of the monitor's academic knowledge, as well as providing a leveling possibility whereas the monitor meets the demands of the students in earlier years. It is a necessary opportunity for the enrolled student to prepare itself for learning activities. Even as a serious experience to break down opinions of limited mind about the global universe implicating learning and teaching, for through it some doubts are clarified, both in the students learning scope and on the educational scope, serving as base to build the educator's identity of the student-monitor.

Besides the monitor's academic and personal development, these activities have served as support to curricular subjects study and, thereafter advise the student to acquire greater knowledge, seeking information and success while fulfilling the program content of such subjects. Given that some subjects have a continuously high level of failure, monitory also has the function to help students to acquire study skill, support with regard to their difficulties. This situation is reinforced by Ferreira by mentioning that "uniting knowledge makes us wiser and more productive. It is necessary to discover new perspectives, dividing and adding up to each other"3.

Variables of many dimensions can hinder learning during childhood and adolescence. However such issue is also customary in higher education. Learning difficulties may be due to cognitive shortfalls that harms knowledge acquiring, as also, in most cases, results only from educational or environmental problems that are not associated to cognitive shortfalls.

This training program aims to provide interdisciplinarity and unite theoryand practice during the developed activities, aiding the teacher, facilitate and maximize students learning, arousing their interest into the importance of the academic subject. Monitoring is an activity that puts the student in interaction with didactic experiences. The teaching routine, class preparation as well as stance training facing the most diverse situations found in teaching, serve as solid bases to those who covet academic carriers.

To avoid difficulties and even to enhance the monitor's efficiency and an ideal performance in the role demanded by this activity, the monitor must be always searching for information and updating itself, to avoid setbacks and inconveniences such as disbelief from the aided students. If the monitor, while student-advisor, loses his identity, the learning process gets misguided, flipping the scales solely to the professor side, causing the monitor to lose its meaning against the class and its leader. This way academic monitoring will contribute very little or, in worst cases scenario, nothing at all to its growth in the teaching approach. The initiative and relevance to study the theme of this paper came from the need to verify if academic monitory contributes in a positive way to the students learning, favoring and supporting the studies, here restricted to the educational scope of Bachelor degree in Odontology, as well as the experience lived by the monitor in its first steps towards teaching, if monitoring can assign relevant considerations as, for example, to evaluate the monitor's profile and if the developed activities guarantee conclusive bases to determine a possible conduction and motivation to a sequence in teaching carrier. 


\section{Materials and Methods}

The monitory activities in Pharmacology (sophomore year) in the Odontology course at the State University "Júlio de MesquitaFilho" Araçatuba's campus were developed on class days and in extra class times. The monitor attended the subject's classes weekly, aiding the students when needed. Furthermore, the monitor would schedule program content reviews to classes of both terms, in a way that they had an explanatory feature in on class and answering doubts and questions on the next. They were all executed in opposite time to the scheduled classes, at night for day time classes and vice-versa.

Outlined study groups with fewer students for better exploitation of the meeting were made, even with the prerogative of answering all doubts and difficulties they had. These study groups took place on the campus library or in the students' home (when these had enough room to accommodate them in an organized and plausible fashion). According to Perpétuo and Gonçalvez ${ }^{7}$. The group dynamic composes a valuable educational instrument that can be used to work the teaching-learning when it chooses an educational conception that values as much as theory as practice and considers all involved in this process as assets.

Another accessory idealized and accomplished was the auxiliary system assistance to home exercise regimen, therefore, the students that went through some kind of scholar withdraw, for example, illness or surgical procedure, were accounted for and aided in their homes to be aware of the contents taught in class and updated as to assignments.

Likewise in the year of 2015, the monitor (first author) created, by his own hand, a study tutorial, which covered all subjects and contents from the politic-pedagogical program of the subject, with the goal to guide and direct the students during the time they would be studying on their own, just as it is imperative to every student the individual dedication to acquire knowledge. In addition, throughout the school year, the students supported by the monitor, held a virtual group to solve exercises or work doubts out on a faster and safest way that involved everyone, so they could share their inquiries, suggestions and deliberations. Parrenoud ${ }^{8}$ highlights that the teacher's figure on formative evaluation demands disposition, and a stance that won't end in the instrumentality, but an active positioning and a teaching methodology planning filled with intentionality to face learning difficulties.

After the development of the monitory in the discipline, a data collection was executed on the institution data base, having as register the information obtained about the number of enrolled students and failures and, afterwards, such data was processed and segmented (related to day-time and night-time courses) to subserve the making of charts, aiming for a better visualization and comprehension of the reached results. To statistical analysis, it was considered as variable the number of failures and as variation factor the presence or not of the monitory in the corresponding school year. The data presented normal distribution and was subjected to variance analysis, followed by Student-Newman-Keuls test. 


\section{Results and Discussion}

Table 1. Percentage of students' disapprovals of the Integral period in the discipline of Pharmacology of FOA / UNESP, according to the school year analyzed

\begin{tabular}{cccc}
\hline School year analyzed & $\begin{array}{c}\text { Number of enrolled } \\
\text { students }\end{array}$ & Number of failures & Failures percentage \\
\hline 2011 & 78 & 12 & $15,3 \% \mathrm{a}$ \\
\hline 2012 & 81 & 09 & $11,2 \% \mathrm{~b}$ \\
\hline 2013 & 79 & 13 & $16,4 \% \mathrm{a}$ \\
\hline 2014 & 76 & 12 & $15,8 \% \mathrm{a}$ \\
\hline 2015 & 74 & 03 & $4,1 \% \mathrm{c}$ \\
\hline 2016 & 78 & 04 & $5,1 \% \mathrm{c}$ \\
\hline
\end{tabular}

Different superscript letters indicate a statistical difference between the percentage of disapprovals in the school years described (Student-Newman-Keuls, $p<0.001$ ).

Table 2.Percentages of failures o nigh-time course students in the Pharmacology subject at FOA/UNESP, according to the school year analyzed

\begin{tabular}{cccc}
\hline School year analyzed & $\begin{array}{c}\text { Number of enrolled } \\
\text { students }\end{array}$ & Number of failures & Failures percentage \\
\hline 2011 & 25 & 05 & $20,0 \% \mathrm{~b}$ \\
\hline 2012 & 28 & 06 & $21,4 \% \mathrm{~b}$ \\
\hline 2013 & 29 & 08 & $27,5 \% \mathrm{a}$ \\
\hline 2014 & 24 & 05 & $20,8 \% \mathrm{~b}$ \\
\hline 2015 & 24 & 02 & $8,3 \% \mathrm{c}$ \\
\hline 2016 & 18 & 00 & $0,0 \% \mathrm{~d}$ \\
\hline
\end{tabular}

Different superscript letters indicate a statistical difference between the percentage of disapprovals in the school years described (Student-Newman-Keuls, $p<0.001$ ).

According to the information contained in the previous charts, it is noted that the Pharmacology subject in the years prior to the start of the monitoring had high levels of failure as can be seen through the percentage (\%) of failures, as much in the day-time course as in the night-time course. After the monitory's annexation to the subject, it is observed on the first year (2015) a reduction in the percentage of failure in both courses (average o 12\% for day-time and $~ 19 \%$ for night-time courses) when compared to the year of 2014 , when there wasn't a monitor performing its role in this activity. As there is a prospect showing high levels of failure in the four prior to the monitory's introduction, it is reasonable to imply that it was ruling for a better performance of the students in the subject and, hence a significant reduction in the number of failures, being categorical in this action, for these are future professionals that will render aid to health and lives of others.

In addition to the mitigation of the failures number, monitory also achieved impressive and lush deeds, since some students that had failed the subject several times in a dependency system were approved. Specifically, one student, that had failed the subject for five years, was given special attention and approach, so through solid accompaniment and motivational assistance the student, that laid unmotivated by the adverse situation, adopted the task of studying as primordial and necessary for his life, being able to overcome the obstacles and difficulties imposed by the content 
and achieved the approval he so longed for, becoming an example for persistency and effort in the pursuit for admission. Indeed, educating an individual presupposes to transform it, help it develop its potential, trying to discover others. It is need to take under consideration the genetic and environmental factors and the interaction between both that education will then modify?

Justifiably, the peculiarity that the monitor when studying the subject himself went through the same difficulties and requisitions made it easy the way he performed his duties, the way he should transmit the information to the monitored students, as well as the understanding related to the problems the students faced and the applicable measure to answer their questionings ${ }^{10}$. According Coelho, from the moment that education starts to understand the principles of the learning process, the problems that may occur in this area will be treated and solved without taboos and without traumas. Once that, considering the intrinsic role of the educator in providing support to the process of learning so the student is able to develop itself safely, in the constant quest for its independence and autonomy ${ }^{11}$. The evaluation of learning is comprehended as a rigorous practice of accompaniment and reorientation of the student, facing the difficulties of learning and thus, ensure students development.

In relation to the total number of failures in the night-time course in the year of 2016, being of $0 \%$, is mainly justifiable for the smaller number of students in class and in a way this made possible to have greater control and perception over the students individual difficulties, as a result, knowledge and information transmission were done in a holistic manner, since the students difficulties were clear, everyone could expose their its setback with less shyness, even because collective experience allowed greater exposition and the immediate feedback cooperated in the students critical analysis development ${ }^{10}$. Another explanation is based on the average class size making it able to combine a diversity of students profile with the monitor's attention. Kokkelenberg ${ }^{13}$ studied the fact that the number of students ( $n$ ) in a classroom interfere in the study-learning e as a consequence in the college students grade. Just as, Bedard and Kuhn ${ }^{14}$, analyzed how the size of the classrooms interfere in the evaluation made by students about teachers' performances, whose smaller classrooms were the ones with the best mentor's efficiency.

A crucial goal of the monitory program is to intensify the cooperation between teachers and students in the academic activities, being processed as something of extreme revolution to contribute to enhance graduation teaching, for in this context, the teacher works in the condition of understanding learning construction process and interfering to lead the group into a redetermination of learning. The interaction between the actors involved around knowledge acquisition becomes a central element in evaluation. Esteban ${ }^{15}$ considers that, to evaluate doesn't mean to judge its learning, it must be a moment that reveals the process of knowledge construction, when the student is not yet aware of its possibilities for advance and overcoming.

The monitoring is a learning space for the student, favoring its personal, academic and professional growth. It tends to refine its abilities as a teacher and motivate it to follow this path, or helps it realize the hardships faced by the professionals in this area, for its own development ${ }^{16}$. In this context, being a monitor propelled the student into an orientation about its professional future, directing it to pursue a carrier in 
teaching and it was a landmark for an evaluation and personal conclusion to define its prosecution area: its ingress in post-graduation.

Thus, it was possible to verify that the monitory had positive effects on the students learning, allowing also verifying that the formative assistance has positive effects in the students formation, ensuring the access to knowledge and it was indispensable to the subjects covered content systematization, since advising and monitoring the students made them acquire greater ease in studying. Furthermore, the presence of the monitor contributes deeply to the right performance of the students, for it enhances academic formation for both aided students and the monitor itself. Therefore it would be viable to institute the monitory in all subjects, when possible; because this is also developed as a positive instrument in the process of facing learning difficulties.

\section{References}

1. Foundation Federal University of Rondônia. Resolution n 129/CONSEA, 2006 Jul 13. [Establishes norms for the Monitoring Program and gives other measures]. Amended by resolution n² 291/ CONSEA, 2012 Oct 23. Portuguese.

2. Cordeiro AS, Oliveira BP. [Academic monitoring: the importance for undergraduate chemistry students]. In: 2nd Meeting of Forensic Science and Expertise of the RN. Natal: ANNQ; 2011 [cited 2018 Jan 25]. Available from: Disponível em http://annq.org/eventos/upload/1325330899.pdf. Portuguese.

3. Ferreira AS, Pacheco AB. [Psychopedagogical intervention in a multidisciplinary perspective: working to develop the potential of adolescent students]. In: Federal Council of Psychology. [Professional experiences in the construction of educational processes in the school]. Brasília: CFP; 2010. p. 53-76. Available from: https://site.cfp.org.br/wp-content/uploads/2010/09/Construcao_de_processos_ educativos_publicacao.pdf. Portuguese.

4. Araujo RB, Tavares LB. [Family and learning difficulties.Pedagogia FAIP]. 2011 Jan 24 [cited 2018 mar 2]. Available from: http://pedagogiafaip.blogspot.com/2011/01/familia-e-dificuldades-deaprendizagem.html. Portuguese.

5. Soares MAA, Santos KF. [Monitoring as a subsidy to the teaching-learning process: the case of financial administration in CCHSA-UFPB]. In: XI Teaching Initiation Meeting. João Pessoa: Federal University of Paraíba; 2008 [cited 2018 mar 5]. Available from: www.prac.ufpb.br/anais/xenex_xienid/ xi_enid/monitoriapet/ANAIS/Area4/4CCHSADCSAMT04.pdf. Portuguese.

6. Sousa Júnior JA, Silva AL, Magno A, Santos MBH, Barbosa JA. [Importance of the monitor in the teaching of organic chemistry in the search of the professional training of the agricultural sciences]. In: XI Teaching Initiation Meeting. João Pessoa: Federal University of Paraíba; 2008 [cited 2018 mar 5]. Available from: ww.prac.ufpb.br/anais/xenex_xienid/xi_enid/monitoriapet/ANAIS/ Area4/4CCADCFSMT03.pdf. Portuguese.

7. Perpétuo SC, Gonçalvez AM. [Dynamics of groups in leadership formation]. Rio de Janeiro: DP\&A; 2005. Portuguese.

8. Perrenoud P. [Evaluation: from excellence to regulation of learning - between two logics]. Porto Alegre: Artes Médicas; 1999. Portuguese.

9. Novaes MH. [School psychology]. Petrópolis: Vozes; 1972. Portuguese.

10. Turner AM, Prihoda TJ, English DK, Chismark A, Jacks ME. Millennial dental hygiene students learning preferences compared to non-millennial faculty members' teaching methods: a national study. J Dent Educ. 2016 Sep;80(9):1082-90 
11. Coelho MT. [Learning problems]. São Paulo: Ática; 1990. Portuguese.

12. Luckesi CC. [Learning evaluation: component of the pedagogical act]. São Paulo: Cortez; 2011. Portuguese.

13. Kokklenberg EC, Dillon M, Christy SM. The effects of class size on student grades at a public university. Econ Educ Rev. 2008 Apr;27(2):221-33.

14. Bedard K, Kuhn P. Where class size really matters: Class size and student ratings of instructor effectiveness. Econ Educ Rev. 2008 Jun;27(3):253-65.

15. Eeteban MT, organizator. [Assessment: a practice in search of new meanings]. Rio de Janeiro: DP\&A; 2001. Portuguese.

16. Oliveira AA, Maia Filho AF, Siqueira LBO. [Monitoring of: the first steps in academic life]. In: XI Teaching Initiation Meeting. João Pessoa: Federal University of Paraíba; 2008 [cited 2018 mar 5]. Available from: www.prac.ufpb.br/anais/xenex_xienid/xi_enid/monitoriapet/ANAIS/ Area4/4CCSADEMT04.pdf. Portuguese. 